\title{
27. CARBON AND HYDROGEN ISOTOPES IN GAS SAMPLES FROM LEG 95, HOLES 603D AND 613'
}

\author{
Michael J. Whiticar and Eckhard Faber, Bundesanstalt für Geowissenschaften und Rohstoffe ${ }^{2}$
}

\begin{abstract}
Methane is the major hydrocarbon gas measured in Vacutainer samples from Holes 603D and $613\left(C_{1} / \Sigma C_{n}>0.999\right)$. In Hole 613 the concentration of this dry hydrocarbon gas is highest $\left(7.4 \times 10^{5} \mathrm{ppm}\right.$ max.) in the upper 60 to $120 \mathrm{~m}$, then decreases erratically to low trace levels by $261 \mathrm{~m}$ sub-bottom (lower Pliocene). No gas accumulations were observed in older sediments. Methane from both holes is strongly depleted in both ${ }^{13} \mathrm{C}\left(\delta^{13} \mathrm{C},-75\right.$ to $\left.-85 \%\right)$ and deuterium (D/H, -175 to $-262 \%$ ), indicating the biogenic origin of the methane. The $\mathrm{C}$ and $\mathrm{H}$ isotopic compositions support methanogenesis via the $\mathrm{CO}_{2}$-reduction pathway; this is also corroborated by the dissolved-sulfate and alkalinity minima at these depths. The relationship between $\mathrm{D} / \mathrm{H}$ of the methane and coexisting interstitial water from Site 613 further show the methanogenesis to be primarily by $\mathrm{CO}_{2}$ reduction.
\end{abstract}

\section{INTRODUCTION}

During drilling of two Deep Sea Drilling Project holes, 603D and 613 of Leg 95, along the New Jersey Transect, gas samples were collected in glass Vacutainers as part of the routine safety monitoring program. The molecular compositions of the gases at Site 613 (down to lower Pliocene) were determined on board and are reported by Whelan et al. (this volume). Gas samples from Holes 603D and 613 were sent to the Bundesanstalt für Geowissenschaften und Rohstoffe (BGR), Hannover, for genetic classification of the hydrocarbon gases using stable carbon and hydrogen isotopes. Additionally, the $\mathrm{CO}_{2}$ from Holes 603D and 613, and interstitial water from Hole 613 , were analyzed for ${ }^{13} \mathrm{C} /{ }^{12} \mathrm{C}$ and $\mathrm{D} / \mathrm{H}$, respectively.

Oxidation of the gas samples for mass spectrometry was as reported by Faber and Stahl (1983). The interstitial water was reduced on zinc using a method similar to that of Coleman et al. (1982). Isotope data are reported in the usual delta-notation relative to the PDB and VSMOW standards.

\section{RESULTS}

Compositions of gases in the Vacutainers from Holes 603D and 613, determined at BGR with a thermal conductivity detector during the preparative GC/oxidation stage for $\mathrm{C}$ and $\mathrm{H}$ isotopes, are listed in Table 1. The very high $\mathrm{CO}_{2}$ contents (up to $45 \mathrm{vol} . \%$ ) found in the BGR samples had not been measured on board (see Whelan et al., this volume), and, together with the correspondingly high nitrogen contents in the samples sent to us, indicate that the Vacutainers had leaked. The high $\mathrm{CO}_{2}$ levels probably resulted from the failure of the $n$ butyl rubber stopper seals on the Vacutainers when the

\footnotetext{
${ }^{1}$ Poag, C. W., Watts, A. B., et al., Init. Repts. DSDP, 95: Washington (U.S. Govt. Printing Office).

Address: Bundesanstalt für Geowissenschaften und Rohstoffe, Stilleweg 2, $3000 \mathrm{Han}$ nover 51, Federal Republic of Germany.
}

dry ice was used to cool the Vacutainers during shipment to BGR. As a consequence, the relative gas composition and $\mathrm{CO}_{2}$ carbon isotope data could not be used.

Methane is the predominant, when not the only, hydrocarbon detected at both sites (Fig. 1). Whelan et al. (this volume) report methane concentrations ranging from 0 to $7 \times 10^{5} \mathrm{ppm}$ (Fig. 1). Ethane is present in only minor amounts ( $<0.1 \%$ of hydrocarbons), and only traces of propane are present, giving a $\mathrm{C}_{1} / \Sigma \mathrm{C} n$ of between 0.999 and 1.000 (Table 1). At Holes 603D and 613, respectively, up to 16 and $9 \mathrm{ml}$ (STP) of methane was available in the 20-ml Vacutainers for isotope analyses. Between Sections 613-7X-2 and 613-10W-1 (119-146.05 m), and for Sections 613-18X-2 and 613-19X-3 (242.28 and $253.59 \mathrm{~m}$ ), insufficient methane or other hydrocarbons were available for carbon or hydrogen isotope analyses. Hydrocarbon gas concentration at Site 613 dropped to zero by $261 \mathrm{~m}$ (lower Pliocene).

Methane at both sites is strongly depleted in ${ }^{13} \mathrm{C}$, by as much as $-80.1 \% 0$ in Section 603D-1-7 and $-84.8 \% 0$ in Section 613-16X-5 (Table 1), and the $\delta^{13} \mathrm{C}$ remains fairly constant with depth (Fig. 1). Similarly, methane is depleted in deuterium, up to $-261 \% 0$ in Section 603D$1-4$ and $-192.5 \% 0$ in Section 613-17X-1.

Interstitial water available from six depths at Site 613 (Table 1) deviated in D/H from the V-SMOW standard by +3.5 to $-1.5 \%$, as shown in Figure 1, becoming slightly more enriched in deuterium in younger sediments.

\section{DISCUSSION}

The hydrocarbons found in Holes 603D and 613 are of biogenic origin. This is indicated by the dryness of the hydrocarbon gas, that is, by the predominance of methane ( $>99.9 \%$ of hydrocarbons), and by the strong depletion of the ${ }^{13} \mathrm{C}$ and deuterium isotopes in the methane (Claypool and Kaplan, 1974; Woltemate et al., 1984). This biogenic classification of the hydrocarbons is clearly illustrated in Figure 2, using a modified diagram from Bernard et al. (1976). The differences between Holes 603D and 613 are due to the small amounts of $\mathrm{C}_{2+}$ detected in 
Table 1. Gas molecules and isotopic composition and $\delta \mathrm{D}_{\text {water }}$ (isotope data reported relative to PDB and V-SMOW standards for $\mathrm{C}$ and $\mathrm{H}$ isotopes, respectively).

\begin{tabular}{|c|c|c|c|c|c|c|c|c|c|}
\hline 2 & 603D-1-4 & 206.00 & 79.9 & 0.10 & 0.999 & 799.4 & -79.7 & -261.8 & \\
\hline 3 & $603 \mathrm{D}-1-4$ & 206.00 & 38.3 & 0.01 & 0.999 & 4782.5 & -75.2 & -175.6 & \\
\hline 4 & $603 \mathrm{D}-1-7$ & 210.50 & 82.5 & 0.07 & 0.999 & 1178.0 & -80.1 & -186.1 & \\
\hline 5 & $613-5 W-1$ & 68.83 & 83.3 & & 1.000 & & -84.5 & -177.1 & \\
\hline 8 & $613-7 X-2$ & 127.10 & 0.0 & & & & & & \\
\hline 9 & $613-7 X-3$ & 130.04 & 0.6 & & 1.000 & & & & \\
\hline 10 & $613-7 X-6$ & 133.85 & 0.2 & & 1.000 & & & & \\
\hline 11 & $613-8 \times-4$ & 139.60 & & & & & & & \\
\hline 12 & $613-8 X-6$ & 142.60 & & & & & & & \\
\hline 13 & $613-9 X-1$ & 144.71 & 0.1 & & 1.000 & & & & \\
\hline 18 & $613-12 X-3$ & 196.04 & 49.2 & & 1.000 & & -81.7 & -184.1 & \\
\hline 19 & $613-12 X-3$ & 197.05 & & & & & & & 2.2 \\
\hline 20 & $613-16 X-5$ & 237.20 & 0.7 & & 1.000 & & -84.8 & & \\
\hline 21 & $613-17 X-1$ & 241.10 & 28.1 & & 1.000 & & -83.3 & -192.5 & \\
\hline 22 & $613-17 X-2$ & 242.70 & 24.1 & & 1.000 & & -83.5 & -182.5 & \\
\hline 23 & $613-17 X-2$ & 243.45 & & & & & & & 1.2 \\
\hline 24 & $613-18 X-2$ & 251.78 & 0.7 & & 1.000 & & & & \\
\hline 25 & $613-19 X-3$ & 263.09 & & & & & & & \\
\hline 26 & $613-22 X-3$ & 292.65 & & & & & & & 1.2 \\
\hline 27 & $613-27 X-3$ & 342.15 & & & & & & & -1.5 \\
\hline
\end{tabular}

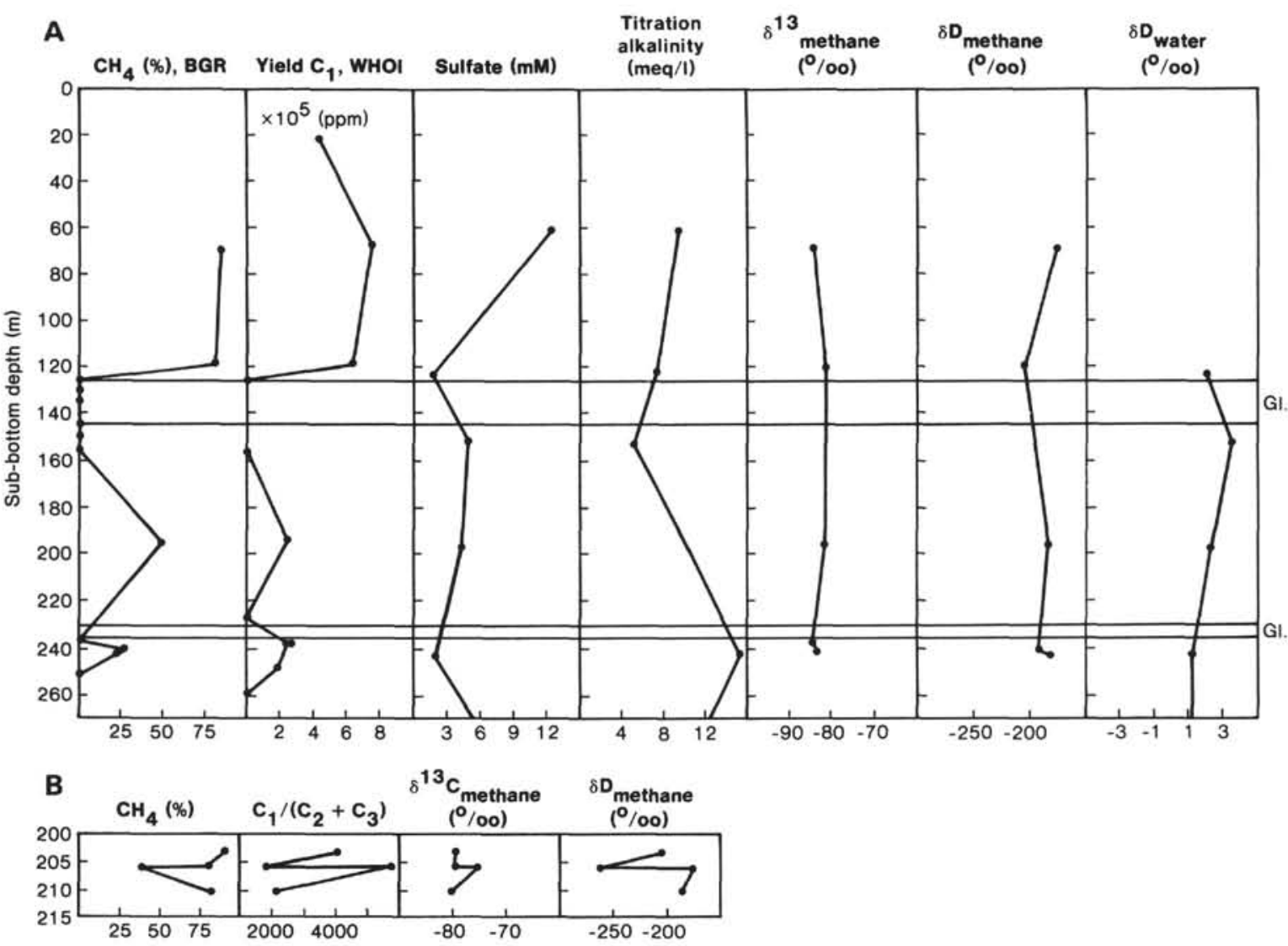

Figure 1. Compositions of Vacutainer gases collected down to $270 \mathrm{~m}$ sub-bottom (lower Pliocene) at (A) Hole 613 and (B) Hole 603D. Depth distribution of methane concentration (in terms of percentage of total gas) is shown, together with hydrocarbon yield and $\mathrm{C}$ and $\mathrm{H}$ isotopic composition. $\mathrm{D} / \mathrm{H}$ of the interstitial water from Hole 613 is presented for comparison, along with data from Woods Hole Oceanographic Institution (WHOI) (Whelan et al., this volume) on methane concentration, dissolved sulfate, and alkalinity. Zones of organic-poor glauconitic sediment are indicated by "gl." D/H of interstitial water is constant with depth. BGR = Bundesanstalt für Geowissenschaften und Rohstoffe (this study). 


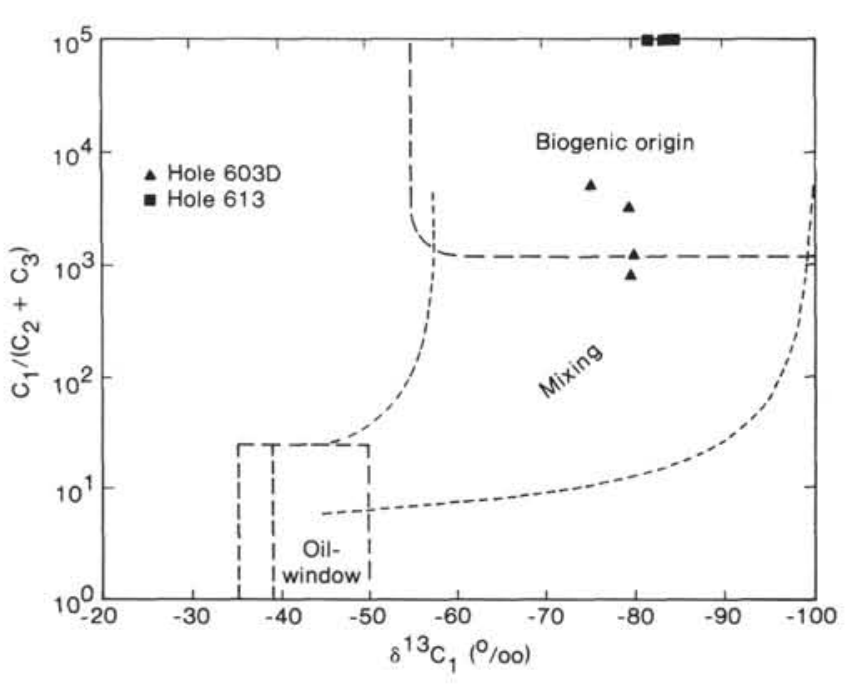

Figure 2. Genetic classification diagram using molecular and carbon isotopic composition (modified after Bernard et al., 1976), showing biogenic character of the hydrocarbon gases from Holes 603D and 613 .

Hole 603D. The minor concentrations of ethane and perhaps propane can be of bacterial origin, often associated with methanogenesis. Trace amounts of higher hydrocarbons may also form, however, by early diagenetic processes (Whelan et al., 1982), but are present in concentrations of only a few ppm at most.

In most marine environments it is observed that significant methanogenesis first occurs after exhaustion of the dissolved sulfate. This is thought to result from the sulfate-reducing bacteria effectively outcompeting the methanogens for the available substrate and hydrogen needed for methane formation. At Site 613 the minimum sulfate concentration generally corresponds to the depth of methane accumulation, although the sulfate levels of 1.7 to $4.9 \mathrm{mM}$ reported for this region by Whelan et al. (this volume) are higher than would normally be expected for extensive methanogenesis. The erratic distribution of the methane and sulfate concentrations down to $250 \mathrm{~m}$ could be evidence of methanogenesis at limited depth intervals with higher organic carbon contents, possibly within restricted microenvironments. This would explain, for example the absence of methane in the organic-poor glauconitic sand zones indicated in Figure 1 at 127.1 to $154.1 \mathrm{~m}$ and 235.0 to $236.2 \mathrm{~m}$. Redistribution of methane either by natural processes such as diffusion, or during drilling and sampling activities, should also be considered for some of the variations noted. The absence of biogenic gas accumulations deeper than $260 \mathrm{~m}$ in carbonate-rich Miocene and Eocene sediments agrees well with other geochemical data. Dissolved-sulfate utilization by the sulfate-reducing bacteria diminishes in the Eocene sediments, probably because of the drop in organic carbon content. This is signified by the return of the sulfate concentration to near marine water values of $12 \mathrm{mM}$ by $400 \mathrm{~m}$ and then its constancy in the older sediments (Whelan et al., this volume). This restriction of organic-matter reminerali- zation is also indicated by the decline in alkalinity below $250 \mathrm{~m}$.

There is no evidence for methane oxidation within the depth intervals sampled. This alteration process would be characterized by a shift in the isotopic composition of the residual methane toward heavier values.

Biogenic methane is formed via two major methanogenic pathways: (1) acetate-type fermentation and (2) $\mathrm{CO}_{2}$ reduction. Several studies have proposed that the latter pathway is dominant in marine sediments, owing to the fact that the precursor acetate is oxidized to $\mathrm{CO}_{2}$ in the sulfate reducing zone. It has been shown that at a later stage, after the removal of the sulfate, this $\mathrm{CO}_{2}$ pool can operate as the sole carbon source for the methanogens. Carbon and hydrogen isotopes have recently been used by the authors (Whiticar et al., 1986) to distinguish between methanogenic pathways. Kinetic fractionation of carbon isotopes between $\mathrm{CO}_{2}$ and methane during methanogenesis is greater for carbonate reduction $\left(\alpha_{\mathrm{c}}=\right.$ 1.055 to 1.08$)$ than that for acetate-type fermentation $\left(\alpha_{\mathrm{c}}=1.04\right.$ to 1.055$)$. As a result, in natural environments methane generated by $\mathrm{CO}_{2}$ reduction tends to be more depleted in ${ }^{13} \mathrm{C}$ than that formed by acetate-type fermentation. Although in sediments there is considerable overlap of values around $\delta^{13} \mathrm{C}=-60 \%$ in methane from the two pathways, methane from $\mathrm{CO}_{2}$ reduction is generally lighter than this, whereas methane from acetatetype fermentation is heavier. The methane $\delta^{13} \mathrm{C}$ measured for Holes 603D and 613 is in the region expected for methanogenesis by $\mathrm{CO}_{2}$ reduction. The dissolved $\delta^{13} \mathrm{C}_{\mathrm{CO}_{2}}$ data are unavailable, as mentioned, but assuming a reasonable $\delta^{13} \mathrm{C}_{\mathrm{CO}_{2}}$ value of $-20 \%$ for bicarbonate added by oxidation of organic matter (Claypool and Kaplan, 1974) to the interstitial water (initial value around zero), the alpha $\mathrm{C}$ for $\mathrm{CO}_{2}-\mathrm{CH}_{4}$ would be around 1.07 , as expected for the $\mathrm{CO}_{2}$-reduction pathway.

In a manner similar to the $\mathrm{CO}_{2}-\mathrm{CH}_{4}$ coexisting pairs, the relationship between the $\mathrm{D} / \mathrm{H}$ of the formation water and the $\mathrm{D} / \mathrm{H}$ of the biogenic methane can also be used to distinguish between methanogenic pathways. Methane formation by $\mathrm{CO}_{2}$ reduction requires that all the hydrogen for the methane ultimately come from the formation water. Incorporation of the methyl hydrogen during acetate-type fermentation, in contrast, necessitates that only one quarter of the hydrogen come from the formation water. Interstitial water from Site 613 has the hydrogen isotopic composition of ocean water. The $\mathrm{D} / \mathrm{H}$ ratios of methane and the corresponding formation water are plotted in Figure 3, from which the proportion of the two formation pathways can be estimated (Woltemate et al., 1984). The uppermost line ( $R$; slope $=1.0)$ describes $100 \%$ methanogenesis of $\mathrm{CO}_{2}$ reduction, and the lowermost line $(\mathrm{F}$; slope $=0.25)$ represents $100 \%$ contribution by acetate-type fermentation. The coexisting $\mathrm{D} / \mathrm{H} \mathrm{CH}_{4}-\mathrm{H}_{2} \mathrm{O}$ pairs from Site 613 indicate that roughly $90 \%$ of the methane can be attributed to methanogenesis by $\mathrm{CO}_{2}$ reduction.

It is also interesting that the alkalinity shows a definite decrease in the major zone of methane generation $(60-120 \mathrm{~m})$. Normally, during remineralization of organic 


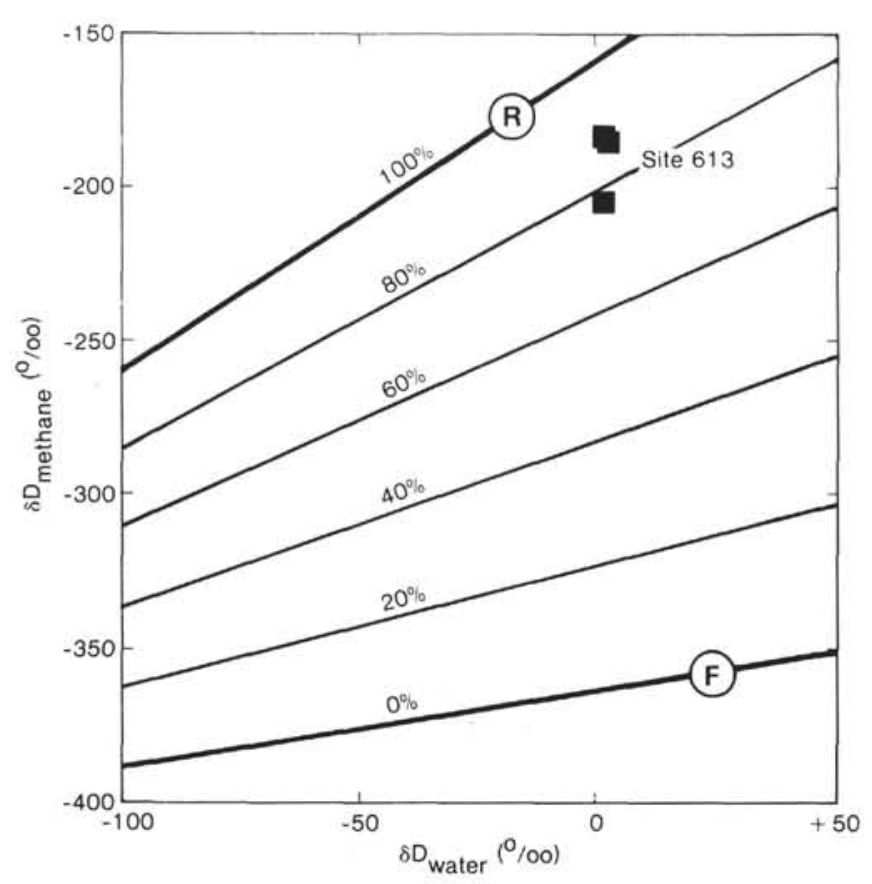

Figure 3. Hydrogen isotope ratios, plotted from the coexisting methane-formation water pairs at Site 613, are used to estimate the proportions of methanogenesis via $\mathrm{CO}_{2}$ reduction (R) and via acetatetype fermentation (F). At Site 613 the former pathway is dominant (roughly $90 \%$ ).

matter, an increase in alkalinity should accompany the reduction of sulfate. The consumption of $\mathrm{CO}_{2}$ provides additional evidence that $\mathrm{CO}_{2}$ reduction is the primary methanogenesis pathway in these two DSDP holes.

The combined carbon and hydrogen isotopic data of methane for both sites in the genetic classification diagram (Fig. 4; Whiticar et al., 1986) confirm the biogenic character and the $\mathrm{CO}_{2}$-reduction pathway of the methane.

\section{ACKNOWLEDGMENTS}

We would like to thank the crew and scientific staff of the Glomar Challenger for their efforts; J. K. Whelan for her coordinating activities; M. E. Tarafa for providing the interstitial water and gas composition data; and S. M. Prinz for sending the interstitial waters for $\mathrm{D} / \mathrm{H}$ analyses. Our work is funded by the B.M.F.T. Grant No. 6237A in Germany.

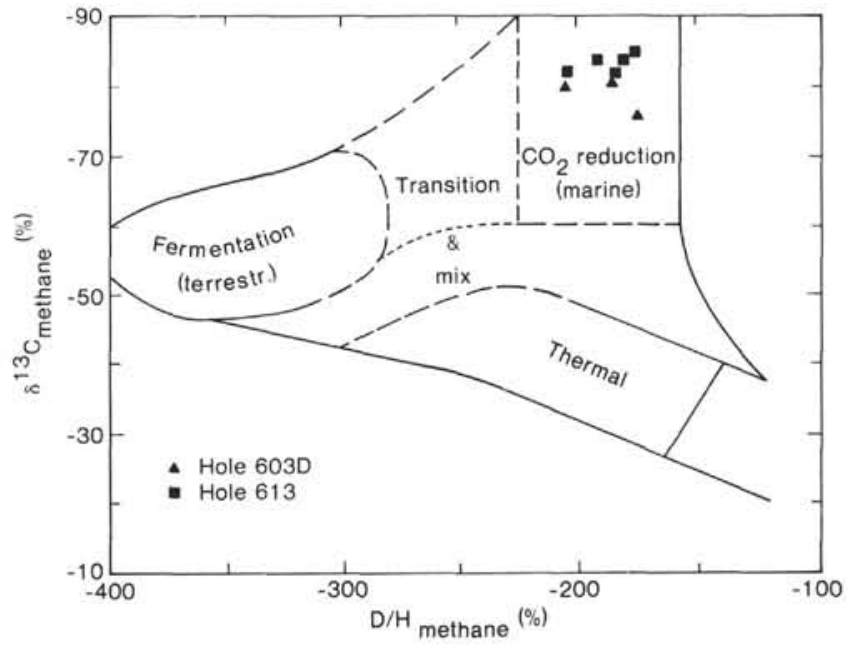

Figure 4. Genetic classification diagram for methane, using $\mathrm{C}$ and $\mathrm{H}$ isotopes (after Whiticar et al., 1986). Isotopic data from both holes confirm the biogenic character of the methane and methanogenesis via $\mathrm{CO}_{2}$ reduction.

\section{REFERENCES}

Bernard, B. B., Brooks, J. M., and Sackett W. M., 1976. Natural gas seepage in the Gulf of Mexico. Earth Planet. Sci. Lett., 31:48-54.

Claypool, G. E., and Kaplan, I. R., 1974. The origin and distribution of methane in marine sediments. In Kaplan, I. R. (Ed.), Natural Gases in Marine Sediments: New York (Plenum Press), pp. 99-139.

Coleman, M. L., Shepard, T. J., Durham, J. J., Rouse, J. E., and Moore, G. R., 1982. Reduction of water with zinc for hydrogen isotope analysis. Anal. Chem., 54:993-995.

Faber, E., and Stahl, W., 1983. Analytical procedure and results of an isotope geochemical surface survey in an area of the British North Sea. In Brooks, J. (Ed.), Petroleum Geochemistry and Exploration of Europe: Oxford (Blackwell Scientific), pp. 51-63.

Whelan, J. K., Tarafa, M. E., and Hunt, J. M., 1982. Volatile $C_{1}-C_{8}$ organic compounds in macroalgae. Nature, 299:50-52.

Whiticar, M. J., Faber, E., and Schoell, M., 1986. Biogenic methane formation in marine and freshwater environments: $\mathrm{CO}_{2}$ reduction vs. acetate fermentation-isotope evidence. Geochim. Cosmochim. Acta, 50:693-709.

Woltemate, I., Whiticar, M. J., and Schoell M., 1984. Carbon and hydrogen isotopic composition of bacterial methane in a shallow freshwater lake. Limnol. Oceanogr., 29:985-992.

Date of Initial Receipt: 24 January 1985

Date of Acceptance: 22 October 1985 